\title{
Myocardial infarction and angina pectoris in the history of Polish medicine
}

\author{
Part 2. Diagnosis and early attempts at treatment: the 19th and 20th centuries
}

\author{
Janusz H. Skalski \\ Department of Pediatric Cardiac Surgery, Polish-American Children's Hospital, Collegium Medicum Jagiellonian University, Kraków, Poland
}

Abstract: In the second part of the article, developments following the "discovery" of ischemic heart disease and gaining understanding of its nature have been presented starting from the first intravital diagnoses of myocardial infarction in the history of the world medicine established by Adam Hammer in Austria (1878) and Edward Korczyński in Krakow (1887). The contribution of Polish clinicians at the turn of the XX century to the first modern attempts at elucidating the nature of myocardial infarction based on the knowledge of anatomopathology and physiology prevalent at the end of the 19th and the beginning of the 20th century has been described. A special role in understanding pathological mechanisms of myocardial infarction was played by such Polish researchers as Władysław Biegański, Józef Pawiński, Zdzisław Dmochowski, Władysław Antoni Gluziński and Marian Franke. The author has described the beginnings of introducing electrocardiography to the diagnostic evaluation of cardiovascular diseases advocated by Napoleon Cybulski and Józef Latkowski. The discovery of adrenaline by Cybulski and Szymonowicz, an event of great importance in the history of cardiology, as well as the introduction of nitroglycerine to clinical practice by Korczyński soon after the preparation was employed for the first time in the world has been presented. The paper further discusses the rapid development of medical knowledge and therapeutic progress in symptomatic treatment of myocardial infarction within the past fifty years - pharmacotherapy and also early attempts at interventions aiming at restoring blood flow in the occluded infarct-related artery. While presenting the role of Polish physicians in the history of cardiology, the author recalls the most important world discoveries associated with understanding the nature of myocardial infarction, initial diagnostic and therapeutic attempts.

Key words: angina pectoris, history of medicine, myocardial infarction

A century had passed since the watershed work of William Heberden concerning angina pectoris (1768) until myocardial infarction, as its most severe complication, was finally diagnosed in the patient's lifetime, based on clinical symptoms.

The first intravital diagnosis was made in 1878 by physician Adam Hammer (1818-1878) in Austria. He described a case of coronary thrombosis in a 34-year old male diagnosed in his lifetime and confirmed by an autopsy after his death. The patient died with symptoms of cardiogenic shock, considerable bradycardia, and just before his death he did not complain of stenocardial pains. The autopsy revealed the total ob-

Correspondence to:

Prof. Janusz H. Skalski, MD, PhD, Klinika Kardiochirurgii Dziecięcej, Polsko-Amerykański Instytut Pediatrii, Collegium Medicum Uniwersytetu Jagiellońskiego, ul Wielicka 265, 30-663 Kraków, Poland, phone: +48-12-658-10-23, fax: +48-12-658-10-81 e-mail: janusz_skalski@poczta.onet.pl

Received: February 1, 2008. Accepted in final form: February 12, 2008

Conflict of interest: none declared.

Pol Arch Med Wewn. 2008; 118 (4): 248-254

Translated by Iwona Rywczak, MD

Copyright by Medycyna Praktyczna, Kraków 2008 struction of RCA orifice due to thrombus filling the whole right Valsalva sinus.

Nine years later, in 1887 in Krakow, a Polish physician, an extraordinary clinician and an excellent scientist, Prof. Edward Sas Korczyński (1844-1905) (Fig. 1), published an article under a characteristic title "Embolia of the coronary artery of the heart (embolia arteriae coronariae cordis) diagnosed in a lifetime". The paper gave an account of a clinical course similar to the one observed by his predecessor worked in Vienna. Unfortunately, Korczyński's article published in Polish remained unknown to the world and has been rarely referred to in the international medical literature. Unfortunately, the original observation, extraordinary research inquisitiveness, a meticulous clinical description (the article was 9 pages long) and, finally, a carefully selected bibliography, put Korczyński's article among the most important clinical reports in medicine of the 19th century [1,2].

The paper by Korczyński, based first of all on clinical aspects, preceded the report by Obraztsov and Strazchesko from Kiev published in 1910. This paper, what should be mentioned, specified the clinical presentation of coronary 


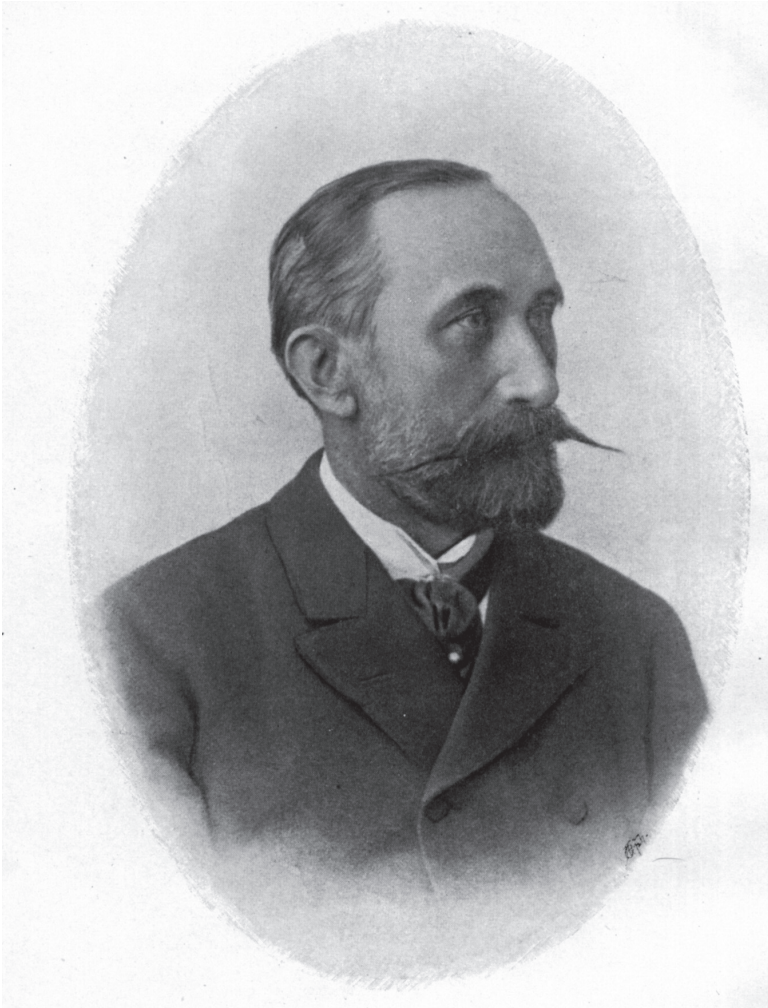

Fig. 1. Edward Sas Korczyński (1844-1905). Reproduced from a collection of Janusz H. Skalski

thrombosis (myocardial infarction), therefore it is regarded as groundbreaking in the field $[3,4]$. Such intravital diagnosis of myocardial infarction made by the eminent American scientist George Dock, the first recorded on American soil (1896), took place much later than in Europe and 9 years after the paper written by Korczyński.

The great significance of Korczyński's report was noticed by our outstanding internist from Częstochowa, Władysław Biegański (Fig. 2), in his textbook entitled "Dyagnostyka różniczkowa chorób wewnętrznych" ("Differential diagnosis of internal diseases"). In the first edition from 1891, on page 115, one could read: "Thrombosis of one of the main branches of coronary arteries brings almost immediate death. Diagnosis of such thrombosis during the lifetime is possible only in some very favorable circumstances. The literature knows only two cases of coronary thrombosis diagnosed during the lifetime, i.e.: one described by Hammer, and another one by Korczyński. in the former, the obstruction process was relatively slow, due to blood clot over the semilunar valve and the patient was alive more than one day afterwards, while in the latter, the patient died within less than 10 minutes, when Prof Korczyński was in the hospital" [5].

More and more often, practicing physicians were making efforts to confirm their diagnoses of angina with an autopsy. They searched for lesions in coronary vessels, already more

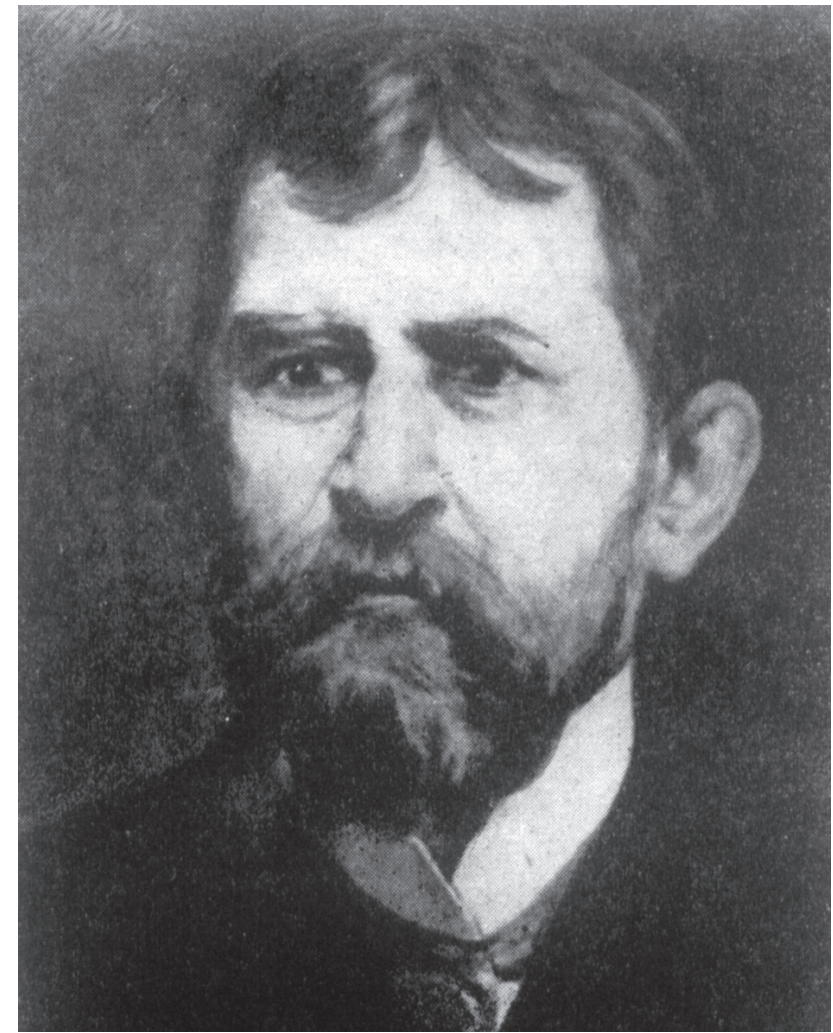

Fig. 2. Władysław Biegański (1856-1917). Reproduced from a collection of Janusz H. Skalski

consciously associating necrotic lesions of the myocardium with the consequence of ischemic heart disease. "Myocardial infarction" was becoming a new diagnosis, not only anatomopathological, but clinical as well. Inventive works on the subject are covered by an early, but perfect, paper on myocardial infarction by Józef Pawiński, a father of Polish cardiology, penned in 1883. The article was entitled Physiological, pathological and clinical aspects of constriction and occlusion of coronary arteries (published in Gazeta Lekarska).

Unfortunately, patients still could not be offered the effective therapy. It pertained both to coronary heart disease and myocardial infarction. A little had been known yet, how the hygienic lifestyle could prevent attacks of angina or how to alleviate sufferings, thus increasing the patient chances to endure the attack. Therefore the agents used for treatment included opium (as well as its derivatives), tranquilizing, spasmolytic, diuretic and relaxant herbs, foxglove, and salts: potassium carbonate, calcium carbonate, magnesium compounds. A watershed in the treatment of angina pectoris was made with the introduction of nitrates. In 1867, an English physician Thomas Lauder Brunton (1844-1916) introduced Amylium nitrosum, a medication, which favorable relaxant effect raises no doubts [6].

However, the introduction of nitrates on a large scale took place only in $1878 / 1879$, after the publication of results of ex- 


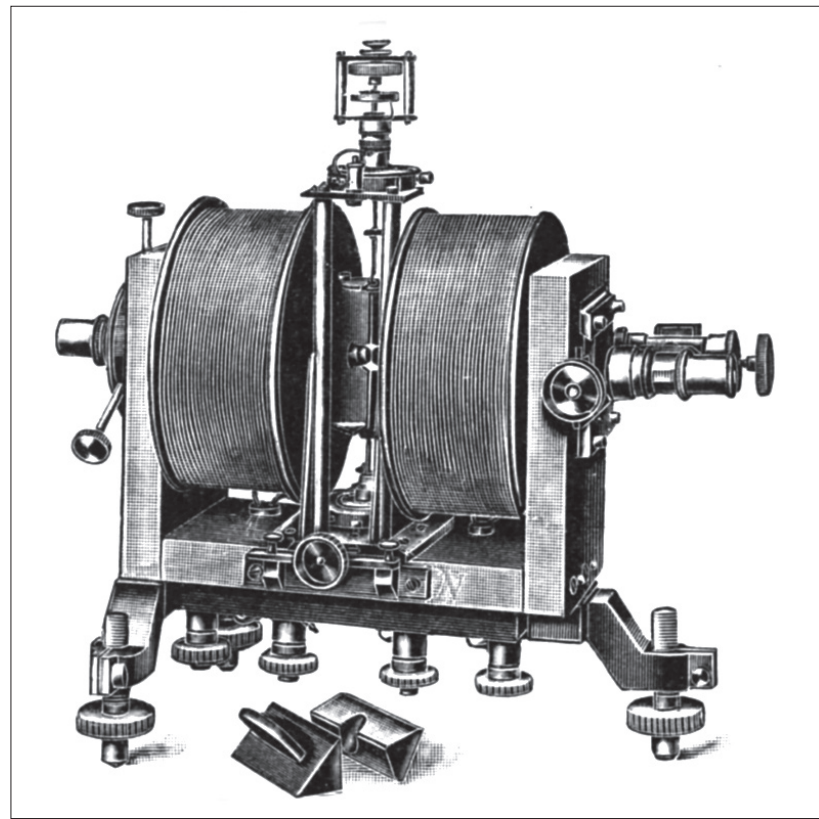

Fig. 3. String galvanometer of Willem Einthoven and Max T. Edelmann (1895). Reproduced from collection of Janusz H. Skalski

periments carried out by an English pharmacologist William Murrell (1853-1912) on the use of gliceryl trinitrate (nitroglycerin). Almost immediately after Murrell's publication, Korczyński introduced nitroglycerin treatment in Krakow. Only two years later, in 1881, his paper on clinical observations of nitroglycerin use was published. Based on experiments carried out together with Michał Janocha, Korczyński introduced nitroglycerin to everyday clinical practice, and used it on a large scale. He administered the agent in the amount of 1-6 drops and observed its effect on the cardiovascular system, lasting from 3 to 45 minutes (with the most distinct effect from 3 to $15 \mathrm{~min}$ ). He described simultaneous effects on the nervous system, manifested in a feeling of warmth in the head and the concentration of difficulties in focusing attention reported by patients [7]. Korczyński gave the following account of nitroglycerin: “(...) nitroglycerin is a drug, which removes attacks of stenocardia very quickly, distinctly and almost entirely (...). It is also probably a powerful medication, soothing the heartbeat caused by any reasons. if stenocardia or heartbeat has no anatomical basis, nitroglycerin could entirely cure those afflictions. in stenocardia caused by aneurisms, nitroglycerin is not only able to eliminate the attacks temporarily, but it may rarely prevent such attacks to some extent" [8].

At the beginning of the 20th century, along with the first experiences with Willem Einthoven's electrocardiograph (1903), the era of still more effective clinical diagnostic evaluation began (Fig. 3).

In 1912, James Bryan Herrick (1861-1954) from Chicago found that using the ECG machine, myocardial infarction might certainly be diagnosed intravitally and the autopsy was

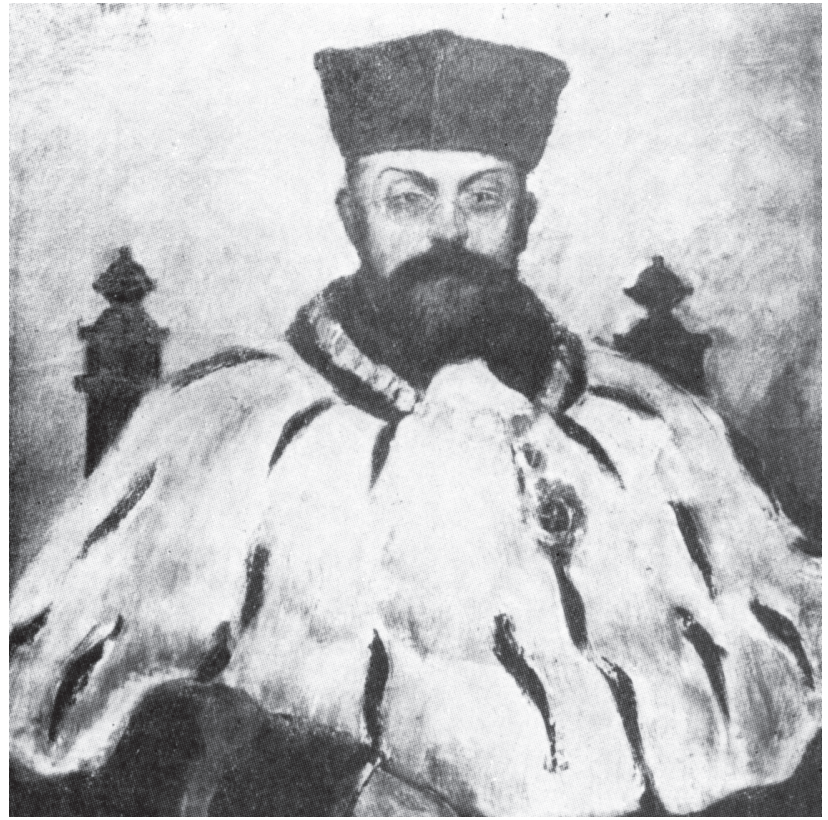

Fig. 4. Napoleon Cybulski (1854-1919). Reproduced from a collection of Janusz H. Skalski

no more the only method to confirm it $[9,10]$. Indeed, from the vantage point of the last century in the history of cardiology, Herrick's works should be considered crucial. an opportunity of intravital myocardial diagnosis made it possible to modify the currently available therapy, alter the general management of a patient and finally enabled to establish the prognosis and reduce mortality.

The following pioneering observations regarding the diagnosis of myocardial infarction made with the use of ECG were carried out by Harold Ensign Bennet Pardee (1886-1973) from New York. In 1920, he presented examples of patients who experienced myocardial infarction (diagnosed based on the typical ECG tracings) and recovered [11].

Poland did not fall behind. The first ECG machine soon started to operate in Krakow, due to a Krakow scientist Napoleon Cybulski (1854-1919) (Fig. 4). Fascinated with Einthoven's inventions, Cybulski was the first Polish researcher who in 1910 managed to obtain the record of heart electrical activity, so he is also the pioneer in the electrocardiography in Poland. He established a physiological research center, well-known in Europe, and a considerable portion of his research made a substantial contribution to the development of science within the field of the cardiovascular system on the international scale. The discovery of a substance contained in adrenal glands and demonstrating strong vasoconstrictor and blood pressure rising properties, made by Napoleon Cybulski and Władysław Szymonowicz in 1895, was among the most significant achievements, which formed the foundations for sciences of hypertension and influenced the later progress in clinical research. The discovered substance was named nadnerczyna (nadnercze is Polish word for "adrenal gland") by Cy- 


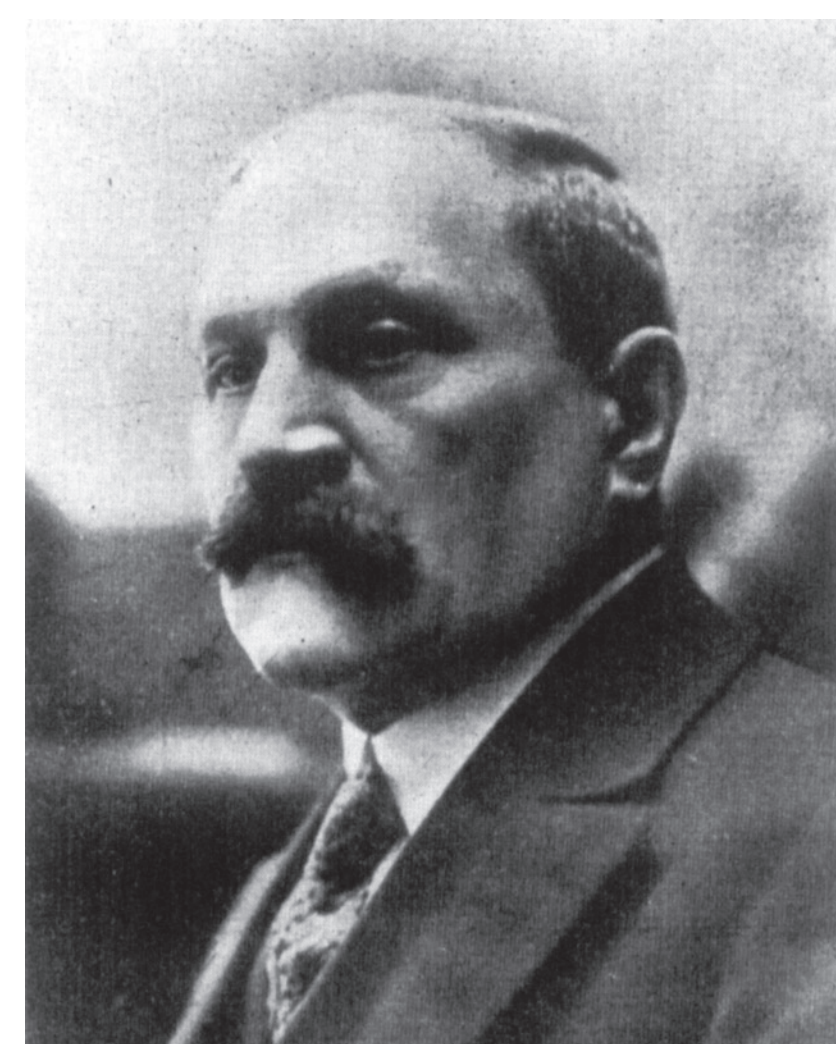

Fig. 5. Józef Latkowski (1873-1848), Dean of the Medical Department of the Jagiellonian University in the interwar period. A pioneer in the use of ECG in Poland. Reproduced from a collection of Janusz H. Skalski

bulski and the term was translated as "adrenaline". It was also in Krakow where a paper describing the ECG record in pericardial obliteration was published for the first time in Poland by Józef Latkowski (Fig. 5). In 1912, the same author published a paper entitled ECG demonstration in dextrocardia vera patient, unusual in the beginnings of the heyday of this diagnostic field.

A perfect and comprehensive textbook by Zdzisław Dmochowski, entitled "Anatomopathological diagnostics", was published in 1903. in the book, it was nothing less than a modern, wise and logical disquisition on myocardial infarction. One of passages reads as follows: "Gradual growth of blood clots and their calcification finally leads to the considerable constriction or complete occlusion of a vessel. Another affliction to cause the complete occlusion of coronary arteries is embolisms (embolia art. coronariae). This phenomenon is among relatively rare ones and usually is a complication resulting from acute endocarditis. in such cases, we determine the diagnosis based on an embolic plug found. The constriction or total occlusion of the coronary arteries has a strong impact on the myocardium (...). Embolism of a coronary artery results in myocardial infarction" [12]. Thus, in the passage quoted above, the term of "myocardial infarction" appears probably for the first time in Polish medical literature. Al- though it is "hemorrhagic infarction" (infactus haemorrbagicus) and not myocardial infarction, which appears in the "Dictionary of polish medical terminology" (1881), where infarction of the uterus is also included [13]. Likewise, the "Polish medical dictionary" of 1905 lacked the term of "myocardial infarction"; it contained "lung infarction" instead. [14]. As late as in 1920, the "Terminology of diseases and causes of death" accepted by the International Committee in Paris and applicable in Europe [15] did not include "myocardial infarction" (only "embolism", "clot" without location stated, in other organs, not in the heart) at all, even as a cause of death!

A well-known textbook, entitled "Science of internal diseases" edited by Walery Jaworski (published in Krakow, 1905), features a well drawn up and extensive section covering heart diseases with references to myocardial infarction by Prof. Korczyński's disciple Władysław Antoni Gluziński (1856-1935), the internal medicine professor of the Lviv University, and since 1919 the Warsaw University. However, in the section of 161 pages, only (or as many as) a half of the page was dedicated to myocardial infarction. Gluziński explained as follows: "Plugs in main stems of coronary arteries (...) cause sudden deaths. Plugs in farther branches are not as dangerous as it may appear from the original experiences, and much depends here on the previous condition of myocardium. The outcome of plugging, if sudden death does not occur, is infarction (infarctus), which softens, and myocardial rupture (ruptura cordis) may appear in this spot, or it is sucked in and larger scar forms in this spot (...)" [16].

The quality, although small textbook, entitled "Diagnostics of cardiovascular system diseases" by a Lviv researcher Marian Franke contains reliable, contemporarily applicable knowledge concerning angina pectoris and cardiac asthma in condensed sections bearing the titles mentioned above. The text is well thought out, diligently drawn up and based on the significant clinical experience of the author. However, we can also find here a little archaic and relatively deeply analyzed subject of "Acute heart exhaustion" [17]. The issue of infarction is considered of a marginal significance by the author, "cramming" laconic information on the issue in a small subsection, entitled "Embolism and thrombus of coronary artery" featured at the end of the textbook and covering only two paragraphs!

Another important Polish textbook from the interwar period, entitled "Pathology, diagnostics and therapy" (1938), edited by Feliks Malinowski and Zenon Orłowski, provided still too little information about the infarction, at least according to our present-day expectations. Still, medicine could not offer too much to a patient. Some progress is perceptible, though. Concerning the infarction treatment (authors of the section: Z. Michalski, H. Skwarczewska) the textbook reads as follows: "The treatment aims at 3 objectives -2 immediate ones (keeping a patient alive and relieving pain and general suffering of a patient) and then, preventing recurrent infarctions. The first two orders require first of all putting a patient in bed, maintaining them as calm as possible at least during 
3-4 weeks, i.e. until possible organizing of the necrotic part of myocardium, with the simultaneous use of all kinds of excitantia (camphor and related agents) and painkillers. Nitroglycerin is of no effect here, it is even probably harmful, lowering blood pressure, which is still low. Large doses of morphine are necessary, although it is not recommended in theory due to the fact that as a vagotonic agent, it constricts the vessels (...)" [18].

\section{Myocardial infarction over the last fifty years}

Over the last decades, prevention and treatment of myocardial infarction have become one of the greatest challenges of contemporary medicine. It is long ago, when it ceased to be a death sentence for a patient, and remained a rare life-threatening conditions definitely requiring medical treatment. The Second World War brought on stagnation in all sciences, including medicine, both in Poland and other European countries tormented by war; to a lesser extent it concerned American medicine, less affected by the tragedy of war.

In the post-war years, Polish physicians were making efforts to keep up with modernity in all fields, although the achievements of our cardiology in that dark age of Polish history took place significantly later than in the Western countries. Nevertheless, Polish cardiologists, despite post-war difficulties and a gap in therapeutic possibilities between the Western world and Poland tormented by war and post-war communist anarchy, strived to keep up with the progress. In the 1940s and '50s, the Western cardiology (chiefly the American one) progress was being checked on. It was due to the fact, as it is hopefully clear from this paper, that Polish physicians were in the vanguard of creation of foundations of the international cardiology, both centuries and decades ago. We should also be aware of the modest diagnostic potential they had, based mostly on the remains from pre-war Poland, taking into account the destruction of the war time.

It was, however, as early as 1945 , when the first Polish publications concerning myocardial infarction by Edward Szczeklik appeared. One of them, particularly worth mentioning for its originality, gave an account of symptoms of damage to the heart conduction system in the course of myocardial infarction $[19,20]$.

It should be pointed out that from the beginnings of records of the Polish medical bibliography, the doctoral theses on the cardiovascular system diseases were written as early as at the beginning of the 19th century (1812). So when could we date the first Polish doctoral theses explicitly referring to myocardial infarction back to? It becomes apparent that it was only after World War II, i.e. 1949 and 1952 [21-23] and then 1961 [24]. Meanwhile, various issues related to the cardiovascular system diseases were quite frequently published in the form of doctoral theses. Suffice it to say that when at the beginning of the 19th century cardiology already started to appear as a harbinger of the new thought and medical specialty, 86 "cardiological" doctoral theses were published by 1961 and only four of them concerned myocardial infarction. in order to make the reader aware of how the interests of the physicians have changed over the years, let us reveal that over the following decade, until 1971, Polish medicine was enriched with another 41 theses directly or indirectly dealing with myocardial infarction [24].

Physicians realized that not so much the non-invasive treatment, introducing all pharmacological novelties, fibrinolytic treatment (both intravenous and intracoronary) and supportive therapy, is the appropriate form of therapy, as the restoration of blood flow in the occluded infarct artery. It was the very solution to become a milestone of the infarction treatment.

René G. Favaloro and Donald B. Effler were the first to initiate surgical reperfusion in acute myocardial infarction. In 1971 they published the first observations concerning this treatment method [25]. The following reports showed that revascularization in acute myocardial infarction is feasible, although it confers high risk [26,27]. With time, the risk of such invasive treatment decreased, and the results in the 1980s started to be appealing. Mortality rate was reduced even to $5 \%$. It became apparent that the main objective of treatment of acute myocardial infarction was to maintain myocardial contractility in the infarction area and thus to reperfuse the infarct artery.

In Poland, surgical reperfusion in patients with acite myocardial infarction was introduced by Zbigniew Religa in 1985 in the Zabrze medical center. In 1988 and 1989, Marian Zembala presented his own experiences in that treatment method [28].

Independently of the progress in surgical treatment of the infarction, in the late 1970s, the new potential of reperfusion of the infarct artery within the scope of modern invasive cardiology emerged. At the same time, the first reports were published on an attempt of invasive recanalization of the infarct artery [29,30] and on the first successful effects of interventional coronary artery reperfusion in acute infarction.

Soon (in 1986), the first Polish paper on that treatment method was published in Warsaw by Dąbrowki et al. [31]. Simultaneously and independently, interventional infarct artery reperfusion was introduced in the Zabrze medical center.

Our knowledge about history ofmyocardial infarction was expanding and evolving along with the progress in medicine based on rational understanding of the human health and disease condition. Over the centuries and millennia, myocardial infarction was a phenomenon or fate deemed completely unintelligible, ominous and even terrifying. Then, gradually, its secret was being revealed, still with respect and distrust whether man could transform the natural course of this disease in any way.

Looking cross-sectionally at the history of understanding, diagnosis and treatment of myocardial infarction, a question arises whether the extraordinary progress of medicine in the 19th and the 20th centuries brought effective treatment, whether medicine managed to overcome the disease? Rather 
not, and the future of the therapy is associated, as it seems today, first of all with genetics and related fields, which means significant interference into molecular biology of a cell. When it comes to revascularization, it should be quite different from the current surgical and interventional approach. And will we be at any time able to say responsibly that myocardial infarction, which has, to some extent, been overcome by us today with respect to understanding and treatment potential, is a thing of the past?

\section{REFERENCES}

1. Korczyński E. Zator tętnicy wieńcowej serca (embolia arteriae coronoriae cordis) za życia rozpoznany. Przegl Lek. 1887; 26: 20-21, 41-43, 57-59, 75-76.

2. Pamiętnik Jubileuszowy wydany ku uczczeniu dwudziestopięcioletniej działalności Prof. Edwarda Sas Korczyńskiego przez byłych jego uczniów. Kraków, Drukarnia C.K. Uniwersytetu Jagiellońskiego pod zarządem J. Filipowskiego, 1900.

3. Obrastzow WP, Staschesko ND. Zur Kenntnissder Thrombose der Coronararterien des Herzens. Ztsch F Klin Med. 1910; 71: 12.

4. Schmidts Jahrbücher der in and Ausländischen Gesamten Medizin. A. Marcus, E. Webers Verlag, Bonn. 1912; 314: 41.

5. Biegański W. Diagnostyka różniczkowa chorób wewnętrznych. Wyd. 1. Warszawa, Wydawnictwo Gazety Lekarskiej, 1891.

6. Dzierżanowski R. Słownik Chronologiczny Dziejów Medycyny i Farmacji. Warszawa, PZWL, 1983.

7. Korczyński E. Kilka słów o działaniu fizjologicznym i o zastosowaniu leczniczym nitrogliceryny. Pam Tow Lek Warsz. 1981; 77: 609-628.

8. Herrick JB. Clinical features of sudden obstruction of the coronary arteries. JAMA. 1912; 59: 2010-2015.

9. Acierno LJ, Worrel T. James Bryan Herrick [Profiles in cardiology]. Clin Cardiol. 2000; 23: 230-232.

10. Callahan JA, Kay JD. Foundations of cardiology. In: Brandenburg R, Fuster $V_{i}$ Gulliani E, McGoon D. Cardiology: fundamentals and practice. Chicago, London, Year Book Med Publ Inc, 1987.

11. Dmochowski Z. Dyagnostyka anatomo-patologiczna. Warszawa, Wydawnictwo Gazety Lekarskiej, 1903.

12. Janikowski S, Oettinger J, Kremer A, Majer J. Stownik terminologii lekarskiej polskiej opracowany przez Komisyją terminologiczną Towarzystwa Lekarskiego Krakowskiego. Kraków, Nakładem Tow Lek Krak, 1881.

13. Browicz T, Ciechanowski S, Domański S, Kryński L. Słownik lekarski polski. Kraków, Nakładem Tow Lek Krak, 1905.

14. Mianownictwo chorób i przyczyn zgonów przyjęte przez Komisję Międzynarodową w Paryżu, dnia 14.10.1920. Ministerstwo Zdrowia Publicznego. Warszawa, 1922.

15. Michalski Z, Skwarczewska H. Zatkanie naczyń wieńcowych. Zawał mięśnia sercowego. In: Malinowski F, Orłowski Z. Patologia, diagnostyka i terapja. Warszawa, Nakładem Warszawskiej Ajencji Wydawniczej „Delta”, 1936.

16. Gluziński A. Choroby serca i naczyń krwionośnych. In: Jaworski W, ed. Nauka o chorobach wewnętrznych. Kraków, Księgarnia H. Altenberga we Lwowie, 1905.

17. Franke M. Diagnostyka chorób narządu krążenia. Lwów-Warszawa-Kraków, Wydawnictwo Podręczników Uniwersyteckich, 1921.

18. Szczeklik E. Przypadek zawału bocznego serca. Przegl Lek. 1945; 1-2: 129.

19. Szczeklik E. Uszkodzenie układu przewodzącego w zawale sercowym jako objaw umiejscowienia. Przegl Lek. 1945; 1-2: 204-216.

20. Stanowski WJ. Zespół Adams-Stokesa we wczesnym okresie zawału mięśnia sercowego (praca doktorska). Kraków, 1949.

21. Jodkowski H. 0 częstości występowania zatorów i zawałów w przebiegu bakteryjnego i przewlekłego zapalenia wsierdzia leczonych penicyliną (praca doktorska) Warszawa, 1952.

22. Stawowiak S. Wpływ czynników bioklimatycznych na występowania zawałów serca (praca doktorska). Kraków, 1952.

23. Smolarz W. Analiza wektorów wieńcowych przestrzennych i odprowadzenia dodatkowe jednobiegunowe w EKG w rozpoznaniu przebytych zawałów tylnej ściany serca (praca doktorska). 1961, Zabrze.

24. Śródka A. Rozprawy doktorskie z zakresu kardiologii na wydziałach lekarskich polskich wyższych uczelni do roku 1974. In: Kuch J, Śódka A. Dzieje kardiologii w Polsce na tle kardiologii światowej. Warszawa, PWN, 1994.

25. Favaloro RG, Effler DB, Cheanvechai C, et al. Acute coronary insufficiency (impending myocardial infarction and myocardial infarction): surgical treatment by the saphenous vein graft technique. Am J Cardiol. 1971; 28: 598-607.

26. Cohn LH, Gorlin R, Herman M, et al. Surgical treatment of acute coronary occlusion. J Thorac Cardiovasc Surg. 1972; 64: 503-513.
27. Sanders CHA, Buckley MJ, Leinbach RC, et al. Mechanical circulatory assistance. Current status and experience with combining circulatory assistance emergency coronary angiography and acute myocardial revascularization. Circulation. 1972; 45: $1292-1313$.

28. Zembala M. Chirurgiczna reperfuzja mięśnia sercowego w świeżym zawale (praca habilitacyjna). Katowice, 1989.

29. Rentrop KP, Blanke $H$, Karsch KR, et al. Initial experience with transluminal recanalization of the recently occluded infarct-related coronary artery in acute myocardial infarction-comparison with conventionally treated patients. Clin Cardiol. 1979; 2: 92-105.

30. Hartzler GO, Rutherford BD, McConahay DR, et al. Percutaneous transluminal coronary angioplasty with and without thrombolytic therapy for treatment of acute myocardial infarction. Am Heart J. 1983; 106: 965-973.

31. Dąbrowski M, Woroszylska M, Jodkowski J, et al. Leczenie ostrego zawału serca przy pomocy przezskórnej środnaczyniowej koronaroplastyki. Kardiol Pol. 1986; 29: 218-226. 